\title{
Current Status of Pyroprocessing Development at KAERI
}

\author{
Hansoo Lee, ${ }^{1}$ Geun-IL Park, ${ }^{2}$ Jae-Won Lee, ${ }^{1}$ Kweon-Ho Kang, ${ }^{2}$ Jin-Mok Hur, \\ Jeong-Guk Kim, ${ }^{1}$ Seungwoo Paek, ${ }^{1}$ In-Tae Kim, ${ }^{1}$ and IL-Je Cho ${ }^{1}$ \\ ${ }^{1}$ Nuclear Fuel Cycle Process Development Division, Korea Atomic Energy Research Institute, 1045 Daedukdaero, Yuseong, \\ Daejeon 305-353, Republic of Korea \\ ${ }^{2}$ Nuclear Fuel Cycle Waste Treatment Research Division, Korea Atomic Energy Research Institute, 1045 Daedukdaero, Yuseong, \\ Daejeon 305-353, Republic of Korea
}

Correspondence should be addressed to Hansoo Lee; hslee5@kaeri.re.kr

Received 10 October 2012; Accepted 5 February 2013

Academic Editor: Hangbok Choi

Copyright (C) 2013 Hansoo Lee et al. This is an open access article distributed under the Creative Commons Attribution License, which permits unrestricted use, distribution, and reproduction in any medium, provided the original work is properly cited.

Pyroprocessing technology has been actively developed at Korea Atomic Energy Research Institute (KAERI) to meet the necessity of addressing spent fuel management issue. This technology has advantages over aqueous process such as less proliferation risk, treatment of spent fuel with relatively high heat and radioactivity, and compact equipments. This paper describes the pyroprocessing technology development at KAERI from head-end process to waste treatment. The unit process with various scales has been tested to produce the design data associated with scale-up. Pyroprocess integrated inactive demonstration facility (PRIDE) was constructed at KAERI and it began test operation in 2012. The purpose of PRIDE is to test the process regarding unit process performance, remote operation of equipments, integration of unit processes, scale-up of process, process monitoring, argon environment system operation, and safeguards-related activities. The test of PRIDE will be promising for further pyroprocessing technology development.

\section{Introduction}

Pyroprocessing treatment can reduced the volume, radioactivity, and heat load of the light water reactor (LWR) spent fuels [1]. In addition, pyroprocessing based on the group recovery of transuranic element (TRU) can provide metal fuels for the sodium-cooled fast reactor while keeping higher intrinsic proliferation resistance. Therefore, successful development of pyroprocessing can save disposal space, reduce the radiotoxicity of spent fuels, and increase uranium utilization efficiency.

Korea Atomic Energy Research Institute (KAERI) has been developing pyroprocessing since 1997. The concept development, bench scale testing, and demonstration of laboratory scale key unit process had been carried out since 2006. From 2007 to 2011, the focus moved to the design and construction of engineering-scale integrated system. Pyroprocess integrated inactive demonstration facility (PRIDE) was constructed in 2011 and it began test operation in 2012.

Process flow diagram consists of head-end processes (decladding, voloxidation, oxide feed preparation), electro- chemical processes (electrolytic reduction, electrorefining, electrowinning), and waste treatment processes as shown in Figure 1.

\section{Unit Process of Pyroprocessing}

2.1. Head-End Process. The head-end process in pyroprocessing is to convert spent fuel assembly into a suitable feed material which is supplied to the electrolytic reduction process.

The first step of head-end process is to disassemble spent pressurized water reactor (PWR) fuel assembly and to extract fuel rods followed by cutting fuel rods of about $4 \mathrm{~m}$ into rodcuts in proper size for decladding process. Disassembling, extraction, and cutting operations of actual spent PWR fuel assembly have been conducted in a laboratory scale for postirradiation examination (PIE) and "Direct Use of PWR spent fuel In CANDU reactors" (DUPIC) experiment in postirradiation examination facility (PIEF).

In order to enhance the decladding efficiency for high burn-up spent fuel, the oxidative decladding efficiency 


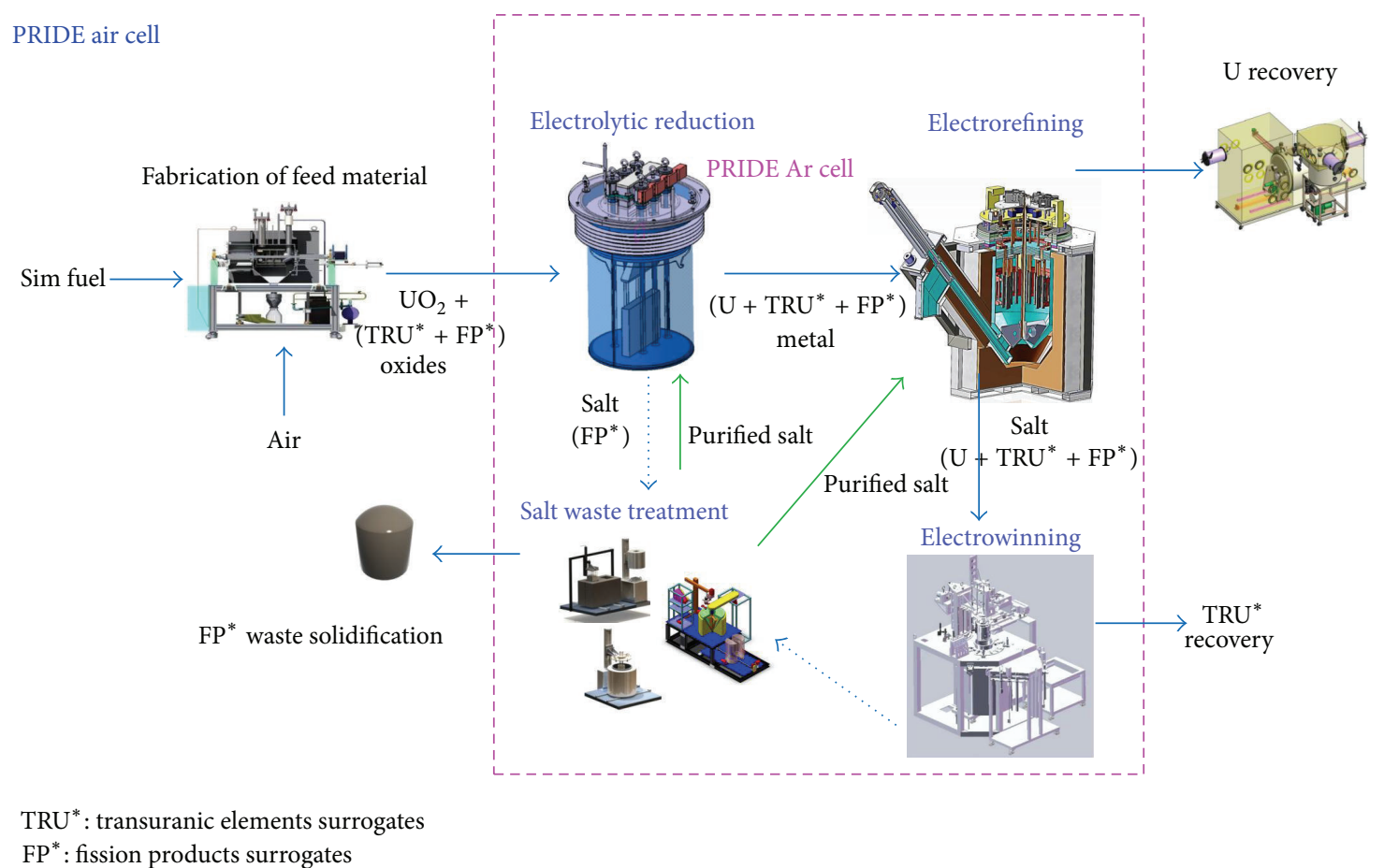

FIGURE 1: Flow diagram of pyroprocessing (PRIDE at KAERI).

without rotation mode was tested. The decladding efficiency was close to $100 \%$ for spent fuel with a burn-up less than $40,000 \mathrm{MWd} / \mathrm{tU}$ when the oxidative decladding with rodcuts less than $30 \mathrm{~mm}$ was performed at $500^{\circ} \mathrm{C}$ for $10 \mathrm{~h}$. On the other hand, spent fuel with a burn-up higher than $50,000 \mathrm{MWd} / \mathrm{tU}$ showed the low decladding efficiency of about $15 \%$ due to small fuel-to-clad gap and low oxidation rate. An improved decladding efficiency higher than 99\% for the high burn-up spent fuel required an oxidation time longer than $20 \mathrm{~h}$ at $700^{\circ} \mathrm{C}$. Therefore, oxidative decladding equipment with rotational device would be required to reduce an oxidative decladding time and obtain the very high decladding efficiency.

Feed material forms such as granule and porous pellet were considered to enhance the current efficiency of electrochemical processes. The particles of $\mathrm{U}_{3} \mathrm{O}_{8}$ powder were bonded together during thermal pretreatment and transformed into aggregates above $1000^{\circ} \mathrm{C}$. In 2009 , a laboratory scale rotary voloxidizer ( $\max .1 .5 \mathrm{~kg} \mathrm{U} \mathrm{U}_{8}$ powder/batch) as shown in Figure 2 was designed and manufactured to investigate particle size controllability for $\mathrm{U}_{3} \mathrm{O}_{8}$ powder. The fabrication characteristics of granule from $200 \mathrm{~g} \mathrm{U}_{3} \mathrm{O}_{8}$ powder was investigated under the conditions of thermal pretreatment temperature of 1150 to $1200^{\circ} \mathrm{C}$ in argon atmosphere, treatment time of 5 to $15 \mathrm{~h}$, and rotational velocity of 1 to $3 \mathrm{rpm}$ using a rotary voloxidizer. Recovery rate of granule higher than $1 \mathrm{~mm}$ with $\mathrm{UO}_{2+x}(0.25<x<0.67)$ composition (Figure 2 ) significantly increased with increasing temperature, rotation velocity, and time of up to $10 \mathrm{~h}$. Typical recovery rate of granule showed about $89 \%(>1 \mathrm{~mm})$ and $98 \%(>0.5 \mathrm{~mm})$. The $\mathrm{UO}_{2}$ granule with density of $4.38 \mathrm{~g} / \mathrm{cm}^{3}(40 \%$ theoretical density (TD)) was fabricated by reduction of $\mathrm{UO}_{2+x}$ at $1000^{\circ} \mathrm{C}$ for $5 \mathrm{~h}$ in $4 \% \mathrm{H}_{2}$-Ar atmosphere. The porous $\mathrm{UO}_{2}$ pellets with density of $6.78-7.67 \mathrm{~g} / \mathrm{cm}^{3}(60-70 \% \mathrm{TD})$ were fabricated by traditional sequential process of compaction and pretreatment (sintering) using the $\mathrm{U}_{3} \mathrm{O}_{8}$ powder obtained by oxidation of $\mathrm{UO}_{2}$ pellets.

Engineering-scale rotary voloxidizer for feed form fabrication was installed at air cell in PRIDE facility in July 2012. Feed form fabrication technology will be demonstrated using simulated fuel pellet from 2013.

An off-gas treatment system for trapping fission products released from oxide feed fabrication process is very important for protecting release of nuclides to environment. In the middle of 1990s, research on the trapping of cesium released from the "Oxidation, REduction of enriched OXide fuel" (OREOX) and sintering processes has started in fabricating DUPIC fuel [2]. Off-gas treatment system for trapping both volatile fission gases such as $\mathrm{H}-3$ and $\mathrm{I}$ in OREOX process and $\mathrm{Cs}$ in sintering process has been established at "DUPIC Fuel Development Facility" (DFDF) as shown in Figure 3(a). It was demonstrated that released Cs from sintering process was completely trapped by fly ash filters. Figure 3(b) shows that approximately $100 \%$ of each cesium isotope released was trapped by using fly ash filter.

2.2. Electrolytic Reduction. The electrolytic reduction process based on the electrochemical reduction in a $\mathrm{LiCl}-\mathrm{Li}_{2} \mathrm{O}$ electrolyte has been developed for the volume reduction of PWR spent fuels and for the supply of metal feeds for the electrorefining process. During the electrolytic reduction process, high heat load fission products dissolve into the chloride molten salt resulting in the decrease of heat load of spent fuels. Additionally, the metallization of oxides to more 


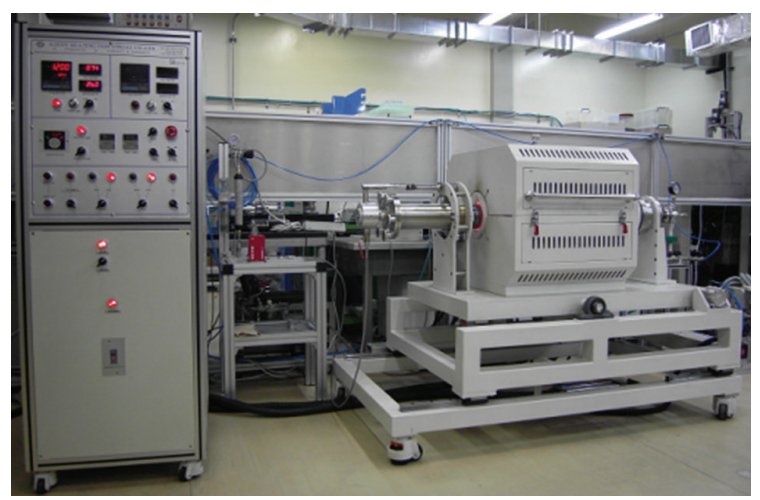

(a)

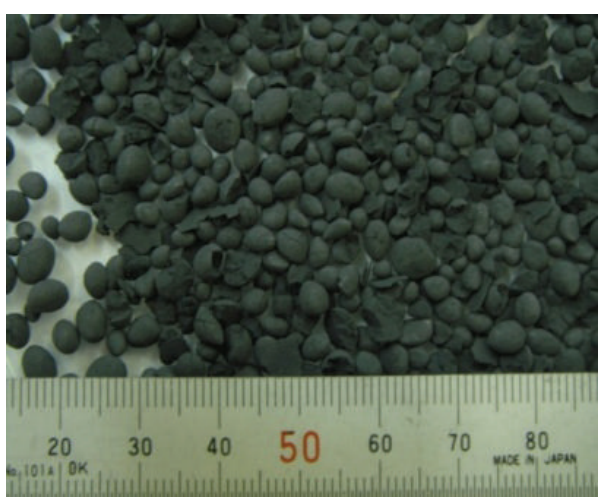

(b)

Figure 2: A rotary voloxidizer (a) and $\mathrm{UO}_{2+x}$ granules (b).

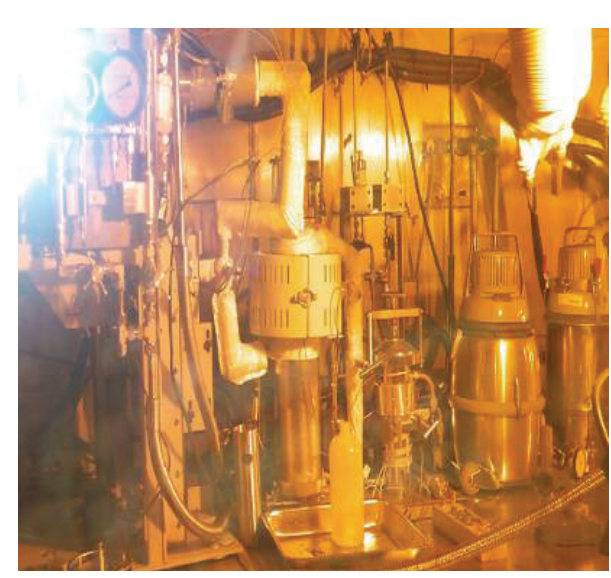

(a) Sintering off-gas trapping system

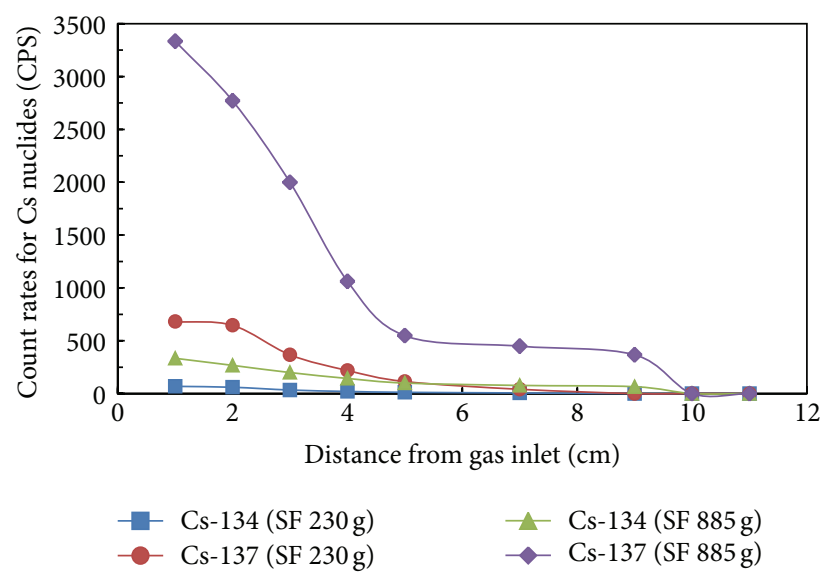

(b) Gamma spectroscopy measurement

FIGURE 3: Off-gas treatment system for DUPIC sintering furnace in DFDF and gamma spectroscopy measurement results of the fly ash filter.

dense metals enables the volume reduction of spent fuels. The metal products produced by the electrolytic reduction process can be directly transferred to the electrorefining process as feed materials. One of the concerning points is the concomitant transfer of residual salts in the metal products to the electrorefining process. The residual salts from electrolytic reduction process, $\mathrm{LiCl}-\mathrm{Li}_{2} \mathrm{O}$, would cause the formation $\mathrm{UO}_{2}$ and the breaking of the eutectic composition in the electrorefining salt, $\mathrm{LiCl}-\mathrm{KCl}$. To address this incompatibility of salts between electrolytic reduction and electrorefining, electrolytic reduction cathode processing was devised for the removal of residual salts in the metal products of the electrolytic reduction process as shown in Figure 4.

2.2.1. Development of Electrolytic Reduction Process. With the progress of electrolytic reduction reaction, the oxide ion from the oxide spent fuel contained in the cathode basket is evolved as gas on the anode leaving the metal spent fuel in the cathode basket, and alkali and alkali earth elements are dissolved into the molten salt. Lanthanides except Eu and metallic fission products remain in the cathode. Consequently, electrolytic reduction process can supply metal feed to electrorefining process and separate selectively the high heat load fission products such as $\mathrm{Sr}$ and $\mathrm{Ba}$ from the spent fuel.

The construction of a newly designed laboratory scale electrolytic reduction system $\left(20 \mathrm{~kg} \mathrm{\textrm {UO } _ { 2 }} /\right.$ batch) was completed at KAERI in 2009 and inactive demonstration has been performed showing high reduction yields up to $99.5 \%$. In 2011, based on the laboratory scale demonstration results, the electrolytic reducer for PRIDE was designed and fabricated to treat $50 \mathrm{~kg}-\mathrm{U}$ per day, which includes a cathode basket with a capacity of $50 \mathrm{~kg}-\mathrm{U}$ loading and 6 anodes (Figure 5).

2.2.2. Development of Electrolytic Reduction Cathode Processor. After the electrolytic reduction process, the residual salt in the cathode basket amounts to about $20 \mathrm{wt} \%$ of the metal products. The cathode process for the removal of residual salts in the cathode basket of the electrolytic reducer can ease the burden of the electrorefining process. The recovered salt in the cathode processor will be treated in the waste salt regeneration process and then recycled to the electrolytic reduction process. The operation of cathode processor is based on the vaporization under vacuum condition.

In 2010, a laboratory scale cathode processor $(4 \mathrm{~kg}$ $\mathrm{LiCl} /$ batch) was installed. This equipment is characterized 


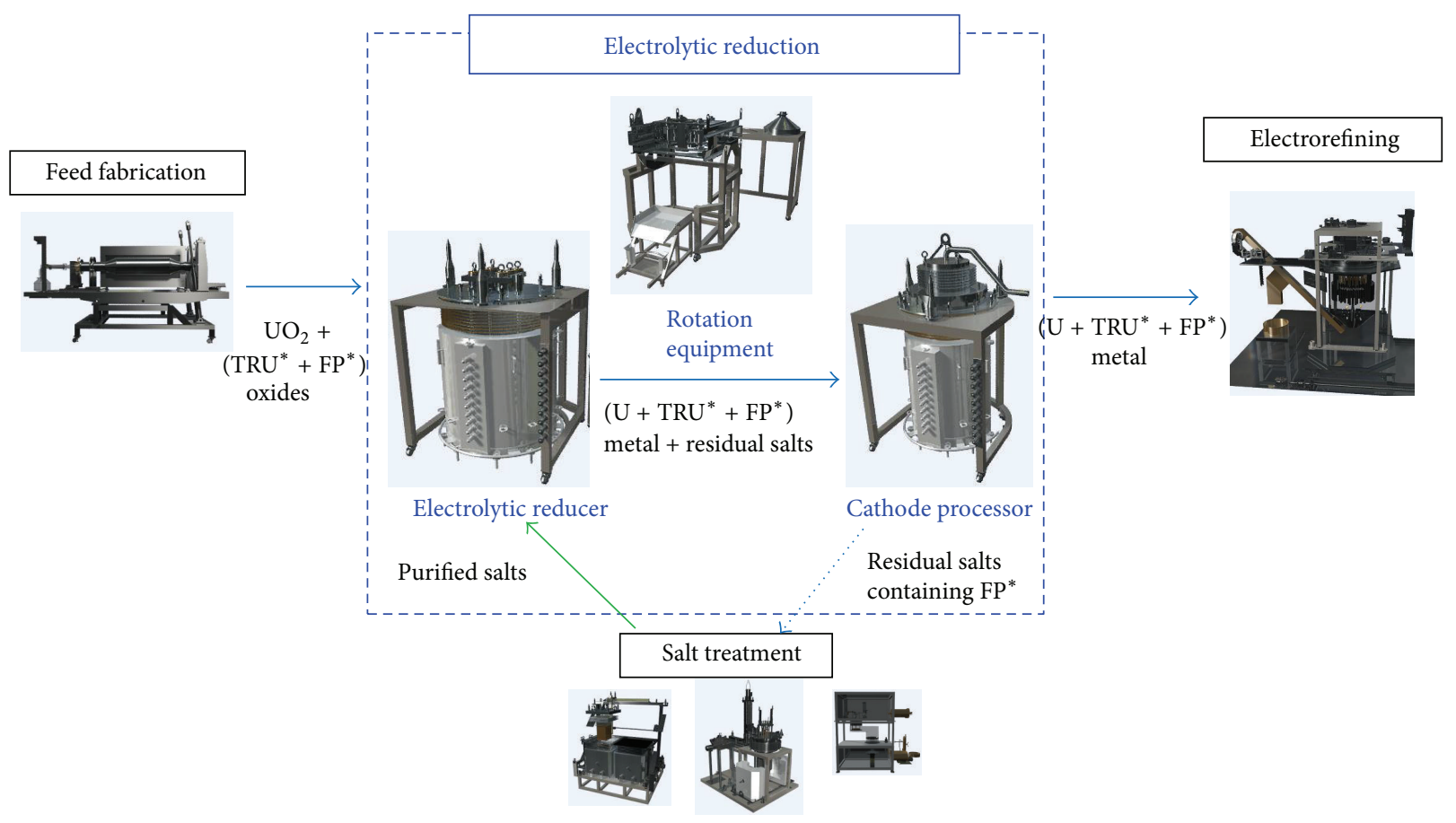

$\mathrm{TRU}^{*}$ : transuranic elements surrogates $\mathrm{FP}^{*}$ : fission products surrogates

FIGURE 4: Electrolytic reduction system.

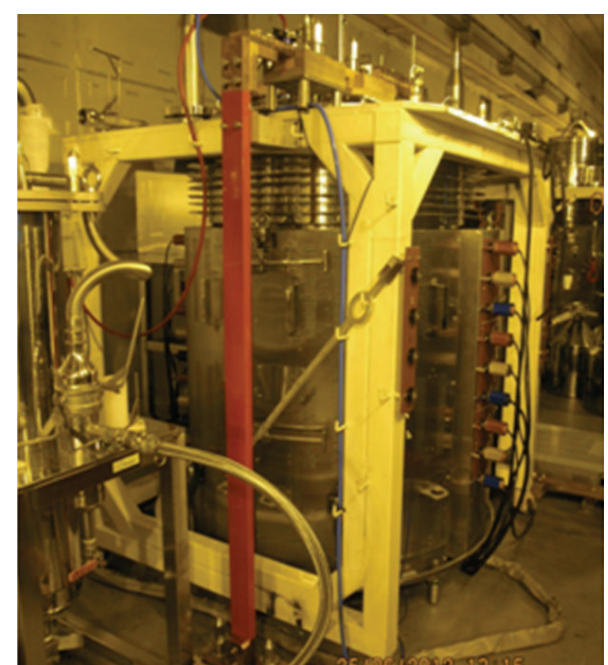

FIGURE 5: PRIDE electrolytic reducer with a capacity of $50 \mathrm{~kg}$ U/batch.

by the maximization of temperature difference between a heating crucible and a receiving crucible. The salt recovered in the receiving crucible is in a powder form, which is easy to handle in a remote operation condition excluding the necessity of hot molten salt transfer. The principle is the condensing of $\mathrm{LiCl}$ vapor as a solid in the cold region of the cathode processor. In an experiment of reduced pressure (100 mtorr) at $900^{\circ} \mathrm{C}$, more than $99 \%$ of the salts were evaporated and recovered nearly $100 \%$ in the receiving crucible.
Based on the laboratory scale demonstration results, the electrolytic reduction cathode processor for PRIDE was designed and fabricated, which can contain two cathode baskets from electrolytic reducer with a capacity of $100 \mathrm{~kg}-\mathrm{U}$ loading (Figure 6).

2.3. Electrorefining Process. Electrorefining, an electrochemical process to recover pure uranium from a metallic or oxide spent fuel, is an essential process in pyroprocessing, because it handles the uranium which is about $93 \%$ of spent fuel. During the electrorefining, the reduced metal from forgoing process, which is composed of uranium, TRU, and rare earth element (RE), is dissolved into a $\mathrm{LiCl}-\mathrm{KCl}$ eutectic salt, whereas only uranium is deposited as a pure dendritic form on a solid cathode. The used salt containing the accumulated TRU and $\mathrm{RE}$ is transferred to electrowinning process.

2.3.1. High-Throughput Electrorefining System. The highthroughput electrorefining system is installed recently in PRIDE. The uranium dendrite is deposited and drawn from the electrorefiner, distilled for salt-removal in salt distiller, and then the salt removed dendrite is consolidated for storage or future use. Uranium trichloride $\left(\mathrm{UCl}_{3}\right)$ is prepared separately and supplied to the electrorefiner. The used salt in an ingot form containing U, TRU, and REs is transported to the next process, electrowinning.

2.3.2. Electrorefiner. In order to increase a throughput of electrorefiner, KAERI has developed the advanced 


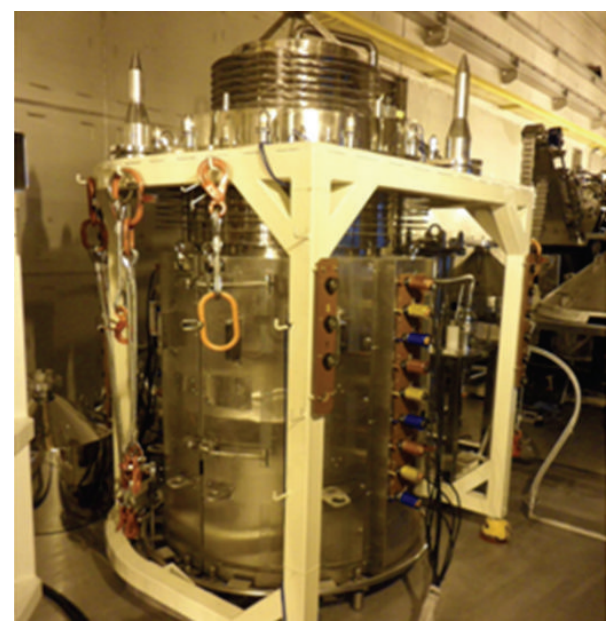

FIGURE 6: PRIDE electrolytic reduction cathode processor with a capacity of $100 \mathrm{~kg}-\mathrm{U} / \mathrm{batch}$.

high-throughput electrorefiner by employing a graphite cathode. The self-scraping mechanism of graphite cathode increases the efficiency of the electrorefiner due to an elimination of the stripping step [3]. In addition, continuous operation of the advanced electrorefiner can be realized by adding a bucket-type deposit transfer system. The 20 $\mathrm{kgU} / \mathrm{batch}$ throughput can be achieved when $40 \mathrm{~kg}$ of simulated fuel pellets are loaded into anode basket and the $\mathrm{UCl}_{3}$ concentration is more than $8 \%$. Recently, the highthroughput electrorefiner was manufactured and installed at PRIDE, which is shown in Figure 7. The electrorefiner for PRIDE was designed to treat $50 \mathrm{~kg}-\mathrm{U}$ per day, which includes 25 graphite cathodes and 4 cathode baskets with a capacity of $100 \mathrm{~kg}$-U loading.

2.3.3. Salt Distiller. The dendritic uranium deposit is drawn out with about $25 \mathrm{wt} \%$ of salt in it from the electrorefiner (Figure 8). To remove the salt for following consolidation process, a vacuum evaporation has been developed in laboratory scale to verify the performance. The engineering-scale salt distiller for PRIDE, which has a capacity of $50 \mathrm{~kg}-\mathrm{U} /$ day, was installed. The salt distiller comprises a distillation tower, a cooler, and a vacuum system. Optimum operation conditions were obtained from the lab-scale experiment at $820^{\circ} \mathrm{C}$ with a capacity of $20 \mathrm{~kg}-\mathrm{U} / \mathrm{b}$ atch, proving that the salt recovery yield was about $97 \mathrm{wt} \%$.

2.3.4. Melting Furnace for Consolidating. The engineeringscale melting furnace for a continuous operation to increase its capacity has been developed. Since the uranium product has a form of dendrite that is difficult to melt by direct heating, a supplemental charge method was developed. The uranium dendrite is gradually added into preexisting molten uranium and tilted toward the molds. The performance of the engineering-scale melting furnace for PRIDE, as shown in Figure 9, was preliminarily evaluated by a melting test of $\mathrm{Cu}$ with a capacity of $50 \mathrm{~kg}-\mathrm{U} / \mathrm{batch}[4]$. An induction heating system with a nonwater cooling coil in an argon gas ambient

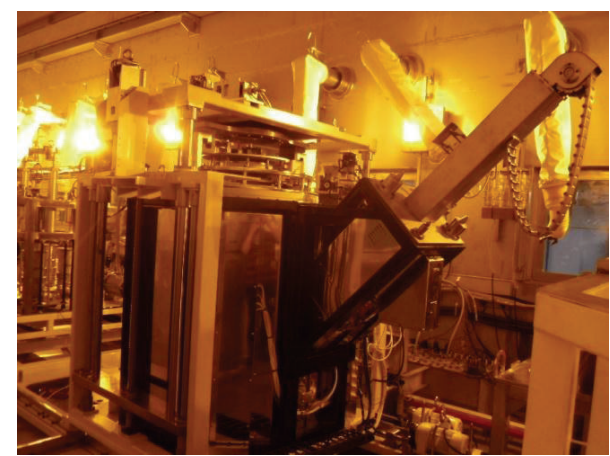

FIGURE 7: Engineering-scale high-throughput electrorefiner with a capacity of $50 \mathrm{~kg}-\mathrm{U} / \mathrm{batch}$.

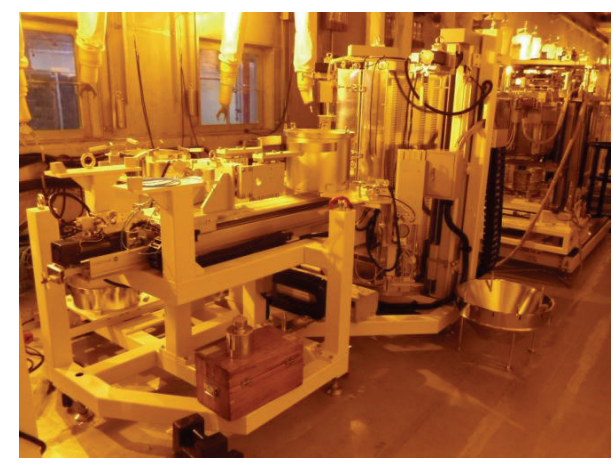

FIGURE 8: Engineering-scale salt distiller with a capacity of $50 \mathrm{~kg}$ $\mathrm{U} /$ day.

was also developed to remove the risk from a reaction of the U-dendrite with water in hot cell. The performance of this nonwater cooling coil was confirmed by a melting test of a cupper [5]. The temperatures of the melting chamber and the heating coils were maintained below $250^{\circ} \mathrm{C}$ and $600^{\circ} \mathrm{C}$, respectively, during the heating test up to $1050^{\circ} \mathrm{C}$.

2.3.5. Uranium Chlorinator. $\mathrm{UCl}_{3}$ plays the role of electrolyte ions to initiate the reaction. It also removes unreduced lanthanide oxides in the anode basket of the electrorefiner and stabilizes the initial cell voltage between electrodes in the electrorefining reactor. The engineering-scale $\mathrm{UCl}_{3}$ fabrication apparatus consists of a chlorine gas generator, a uranium chlorinator, a $\mathrm{Cd}$ distiller, a pelletizer, and an off-gas and dry gas scrubber. The product $\mathrm{UCl}_{3}$ in $\mathrm{LiCl}-\mathrm{KCl}$ is transferred to the $\mathrm{Cd}$ distiller to remove $\mathrm{Cd}$ in $\mathrm{UCl}_{3}$ and then transferred to a pelletizer to form a pellet which could be supplied easily to electrorefiner. The engineering-scale uranium chlorinator with a capacity of $30 \mathrm{~kg}$-U/batch, as shown in Figure 10, was installed recently for PRIDE.

2.3.6. Molten Salt Transport System. As the electrorefining operation proceeded, TRU and RE are accumulated in 


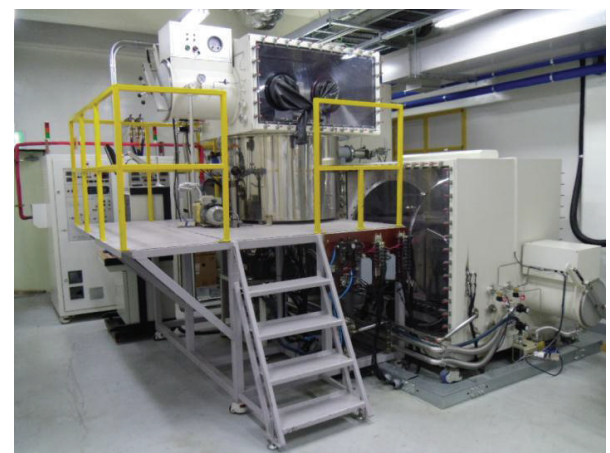

FIGURE 9: Engineering-scale melting furnace with a capacity of $50 \mathrm{~kg}-\mathrm{U} / \mathrm{batch}$.

electrolyte LiCl-KCl salt. KAERI has developed the salt transport system by evacuating the used salt for the transfer to the following electrowinning process [6]. The preliminary lab-scale experiments showed $99.5 \%$ transport rate (ratio of transported salt to total salt) under vacuum range of 100 mtorr 10 torr at $500^{\circ} \mathrm{C}$. An engineering-scale molten salt transport system for PRIDE was installed, as shown in Figure 11.

2.4. Electrowinning System. Electrowinning process is a step of pyroprocessing for the simultaneous recovery of $U$ and TRUs from the remaining salt after electrorefining process using a liquid cadmium cathode (LCC), imposing higher nuclear nonproliferation. The electrowinning process developed at KAERI consists of three steps (Figure 12): (i) LCC electrowinning for simultaneous recovery of $U$ and TRU using an LCC, (ii) residual actinide recovery (RAR) process for recovery of the residual low-concentration U/TRU in the salt after the LCC electrowinning process, and (iii) $\mathrm{Cd}$ distillation of the cathode product (i.e., $\mathrm{Cd}$ ingot including the U/TRU deposits) produced from the LCC electrowinning and the RAR processes. The essential technologies that include the development of effective LCC structure [7], RAR methods [8], analytical technologies [9], and computational model of electrowinning cell [10] have been developed to enhance the operation efficiency of electrowinning process. In order to demonstrate the developed technologies, the engineering-scale electrowinning system of PRIDE was established.

2.4.1. LCC Electrowinning Process. The electrowinning technique using an LCC is a key step for a nonproliferation because TRU could be codeposited with uranium in liquid cadmium. However, the $\mathrm{U}$ ion was known to be deposited in the shape of dendrite on the surface of the liquid cathode [11]. This $U$ dendrite hinders a codeposition of the $U$ and TRU elements. Therefore, the inhibition of the growth of uranium dendrites in the LCC has been considered a critical technique for the electrowinning process. KAERI has developed a meshtype LCC assembly (i.e., mesh agitator with LCC) to prevent $\mathrm{U}$ deposits from growing into dendrites, resulting in the increase of $U$ recovery [7]. The mesh agitator pushes the $U$

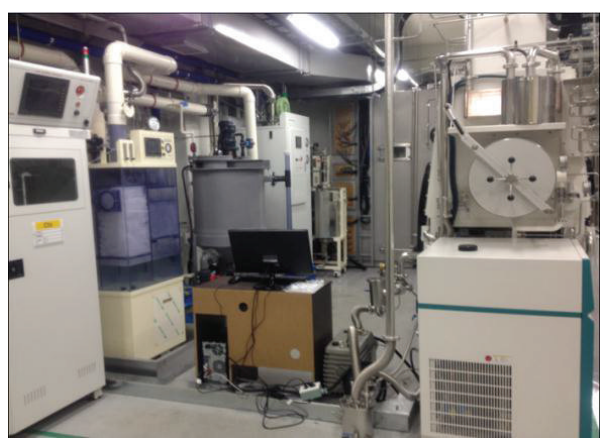

FIGURE 10: Engineering-scale uranium chlorinator (30 kg-U/batch).

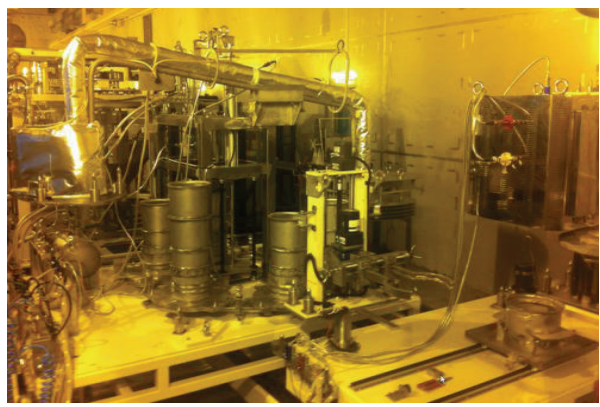

FIGURE 11: Engineering-scale molten salt transport system.

deposits generated on the LCC surface into the liquid Cd. Then $\mathrm{U}$ deposits sink into the liquid $\mathrm{Cd}$ and are gathered at the bottom of the LCC crucible. The performance of the mesh agitator was evaluated in lab-scale LCC experiments. From this experiment, $14 \mathrm{wt} \% \mathrm{U} / \mathrm{Cd}$ was successfully collected without the growth of dendrite out of the LCC crucible.

An engineering-scale PRIDE LCC electrolytic system was designed and constructed based on the lab-scale LCC experiments and the computational simulation results of heat transfer and current distribution [12]. The LCC electrowinning equipment installed in PRIDE and its recovery capacity of heavy metal is $1 \mathrm{~kg}$ heavy metal (HM)/batch (Figure 13).

2.4.2. Residual Actinides Recovery Process. RAR process has been developed by combining the electrolysis using an LCC to collect most the residual actinides in a spent salt phase and an oxidation of a part of the rare earth fission products codeposited onto an LCC by a $\mathrm{CdCl}_{2}$ oxidant [13]. The same electrowinning equipment using an LCC for a recovery of the fuel material can be used for RAR operation. Therefore, the RAR process has promising merits, such as compact equipment and a simple process to operate in a hot cell [14]. The PRIDE RAR processing equipment was designed and installed in the argon cell of the PRIDE.

\subsection{Waste Treatment Process}

2.5.1. Metal Waste Treatment Process. Metal wastes generated from the head-end process of spent fuel are mainly composed of cladding hulls and structural parts. A trace of actinides, such as $\mathrm{U}, \mathrm{Pu}, \mathrm{Am}$, and $\mathrm{Cm}$, and fission products (FPs) 


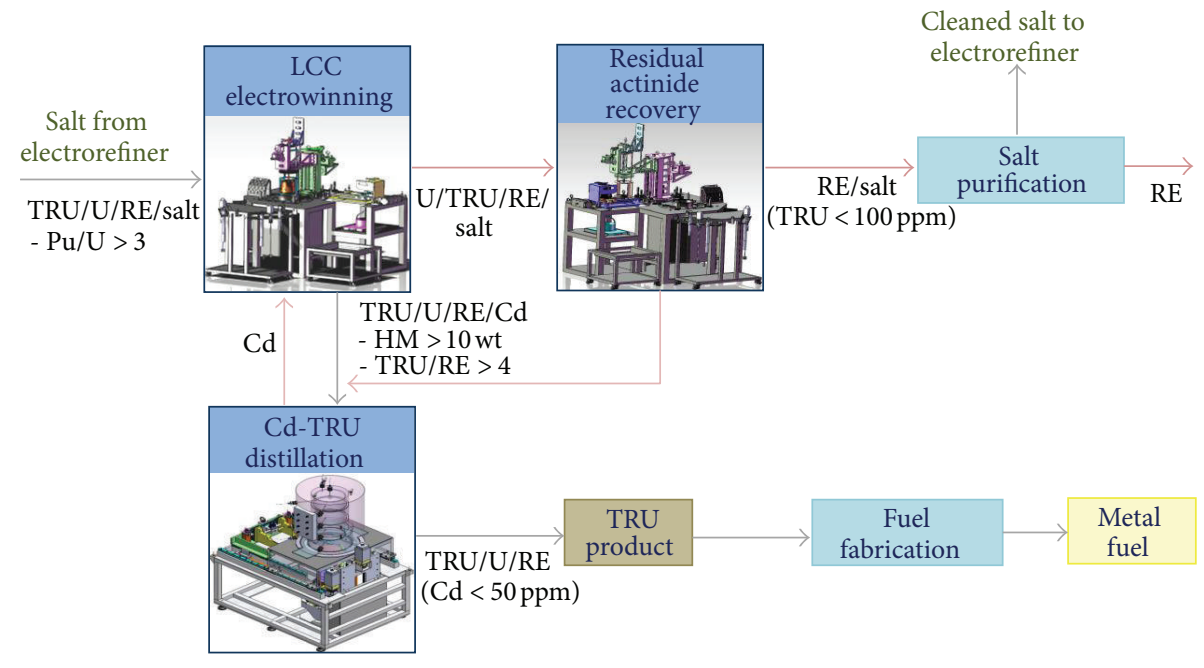

FIGURE 12: Schematic diagram of electrowinning system of KAERI.

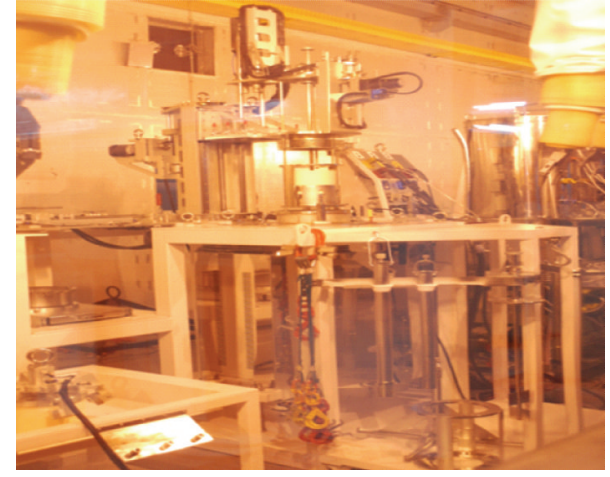

FIGURE 13: PRIDE LCC electrowinning equipment.

penetrate into the inner layer of zircaloy cladding hulls. Structural parts made of various stainless steels, Inconel, and zircaloys are also activated, resulting in the generation of Co60 by neutrons created during a fuel irradiation process in the reactor. Table 1 shows the amount of metal wastes by volume and mass before and after the treatment. It was assumed that the stacking density of the cladding hull was $980 \mathrm{~kg} / \mathrm{m}^{3}$ and actual density of a cladding hull ingot after induction melting was $80 \%$ of theoretical density. In addition, the volume reduction of the fuel hardware by 500 ton compaction was assumed to be $1 / 8$.

Two major streams of the metal waste treatment for storage or disposal are the compaction and melting processes. The melting process has a higher volume reduction factor compared to the compaction method while it is a high temperature process that accompanies higher energy and cost. $\mathrm{Zr}$ recovery from zircaloy cladding hulls correspond to an alternative technology that can reduce the amount of a high level waste and reuse expensive $\mathrm{Zr}$ metal through a recycling process.
2.5.2. Waste Salt Treatment Process. The waste salt treatment process is divided into two parts: $\mathrm{LiCl}$ waste salt at $650^{\circ} \mathrm{C}$ and eutectic $(\mathrm{LiCl}-\mathrm{KCl})$ waste salt treatment at around $700^{\circ} \mathrm{C}$. In $\mathrm{LiCl}$ waste salt treatment process, Groups I and II fission products involved in $\mathrm{LiCl}$ waste salt are removed by using a melt crystallization process and then the remaining residual $\mathrm{LiCl}$ salts containing high content of Groups I and II fission products, such as Cs, $\mathrm{Sr}$, and $\mathrm{Ba}$, are immobilized by mixing with an inorganic matrix, Si-Al-P (SAP) complex, and sintering at $1,200^{\circ} \mathrm{C}$, to the ceramic waste forms. Rare earth fission products bearing eutectic waste salt from the RAR process is treated by successive rare earth removal processes: a combination of oxygen sparging, layer separation, and vacuum distillation/condensation process. Finally, the remaining rare earth oxides (or oxychlorides) are fabricated into the durable ceramic waste forms by mixing with zinc titanate (ZIT) matrix and sintering at $1,200^{\circ} \mathrm{C}$. During each waste salt treatment process, pure $\mathrm{LiCl}$ and eutectic $(\mathrm{LiCl}-$ $\mathrm{KCl})$ salts were recovered for reuse with a high regeneration ratio. Figure 14 shows a brief process diagram of the waste salt treatment process currently being developed by KAERI.

(1) LiCl Waste Salt Regeneration Process. For the reuse of $\mathrm{LiCl}$ waste salt, Groups I and II fission products have to be separated from the $\mathrm{LiCl}$ waste salt. To separate Groups I and II fission products such as $\mathrm{Cs}$ and $\mathrm{Sr}$, chemical agents addition method and ion-exchange method were tested [15-18]. However, the results showed that simultaneous separation of $\mathrm{Cs}$ and $\mathrm{Sr}$ from the $\mathrm{LiCl}$ molten salt via various chemical agents or ion-exchange by zeolite was nearly unlikely [19]. To overcome these difficulties for the separation of both cesium and strontium, a layer crystallization process, which uses the solubility difference of impurities (FPs in this case) between a solid (=crystal) and a melt phase was introduced.

Layer crystallization is a very simple process, which uses cooled plates immersed in a melt for crystal formation, where a crystal grows as a compact crystalline layer on a cooling 
TABLE 1: Composition of pretreatment process wastes (10 ton/MTU).

\begin{tabular}{lcccccccc}
\hline & \multicolumn{4}{c}{ As generated } & \multicolumn{3}{c}{ After treatment } \\
& $\begin{array}{c}\text { Mass } \\
(\mathrm{kg})\end{array}$ & $\begin{array}{c}\text { Composition } \\
(\%)\end{array}$ & $\begin{array}{c}\text { Volume } \\
\left(\mathrm{m}^{3}\right)\end{array}$ & $\begin{array}{c}\text { Composition } \\
(\%)\end{array}$ & $\begin{array}{c}\text { Mass } \\
(\mathrm{kg})\end{array}$ & $\begin{array}{c}\text { Composition } \\
(\%)\end{array}$ & $\begin{array}{c}\text { Volume } \\
\left(\mathrm{m}^{3}\right)\end{array}$ & $\begin{array}{c}\text { Composition } \\
(\%)\end{array}$ \\
\hline Cladding hulls & 2.454 & 70.3 & 2.50 & 35.7 & 3.028 & 74.5 & 0.46 & 45.1 \\
Fuel Hardware & 1.037 & 29.7 & 4.50 & 64.7 & 1.037 & 25.5 & 0.56 & 54.9 \\
\hline Sum & 3.91 & 100 & 7.00 & 100 & 4.065 & 100 & 1.02 \\
\hline
\end{tabular}

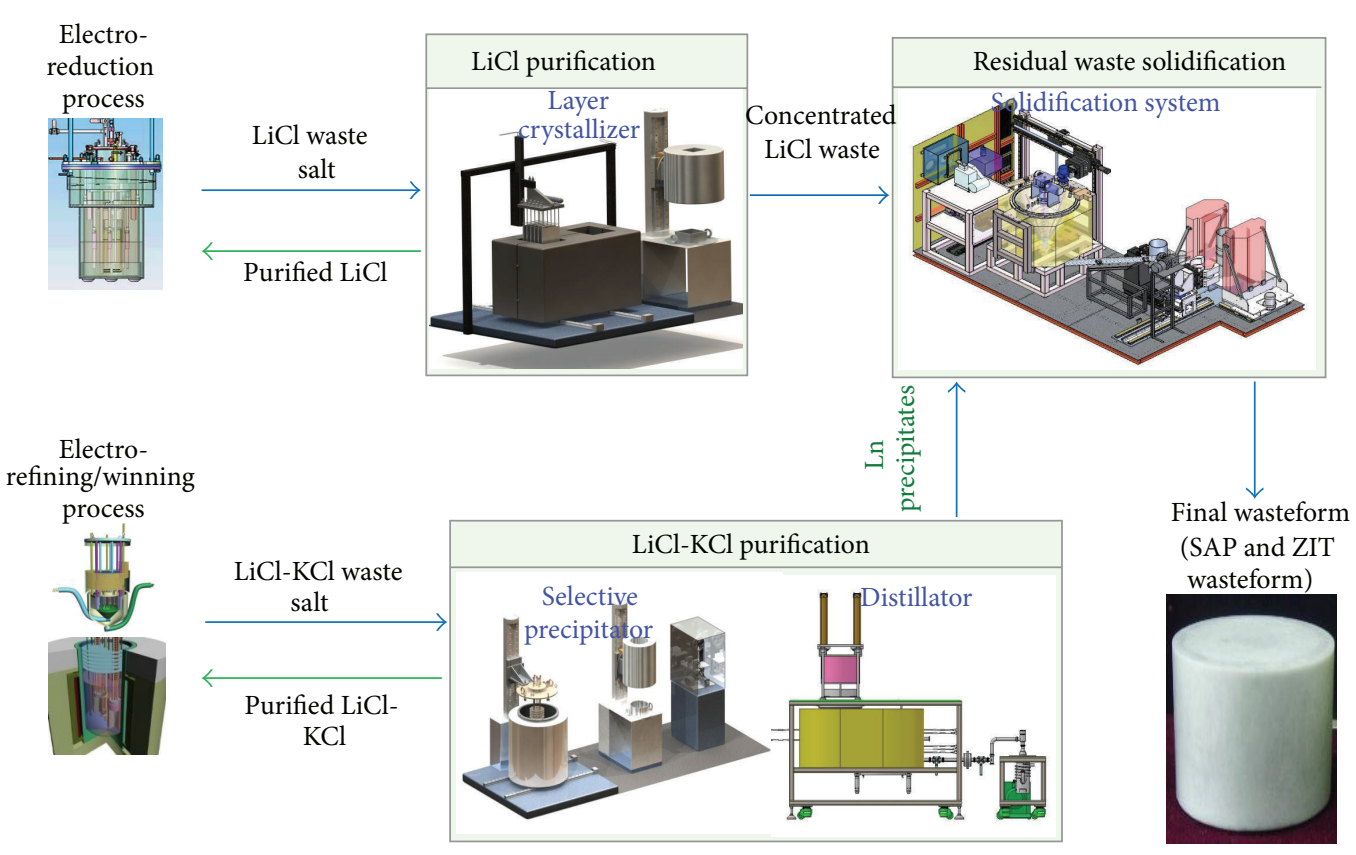

FIGURE 14: Schematic diagram of waste salt treatment process of KAERI.

surface. With the laboratory-scale layer crystallization apparatus (maximum batch size: $4 \mathrm{~kg} / \mathrm{batch}$ ), about $80 \sim 90 \%$ of $\mathrm{LiCl}$ salt containing small amount impurities, Groups I and II fission products can be recovered and the remaining $\mathrm{LiCl}$ in the crystallization furnace with most of impurities is transferred to the immobilization process to fabricate the final waste form.

Figure 15 shows the PRIDE engineering-scale $\mathrm{LiCl}$ waste salt treatment apparatus of which the maximum capacity is $25 \mathrm{~kg}-\mathrm{LiCl} / \mathrm{batch}$ composed of a layer crystallization and a solid $\mathrm{LiCl}$ salt detachment device.

(2) Eutectic (LiCl-KCl) Waste Salt Regeneration Process. Rare earth chloride elements involved in $\mathrm{LiCl}-\mathrm{KCl}$ eutectic waste salt were converted to their molten salt-insoluble precipitates in the oxidative precipitation step by an oxygen gas sparging method. After a full precipitation of these lanthanide precipitates, an eutectic waste salt is separated into two layers: an upper pure (or purified) salt layer and a lower precipitate layer. The upper pure salt layer can be mechanically separated from the precipitate layer, where the separated pure salt layer could be reused (1st pure salt recovery). Then, the adhering eutectic salt involved in the precipitate layer was separated and recovered in the distillation/condensation step (2nd pure

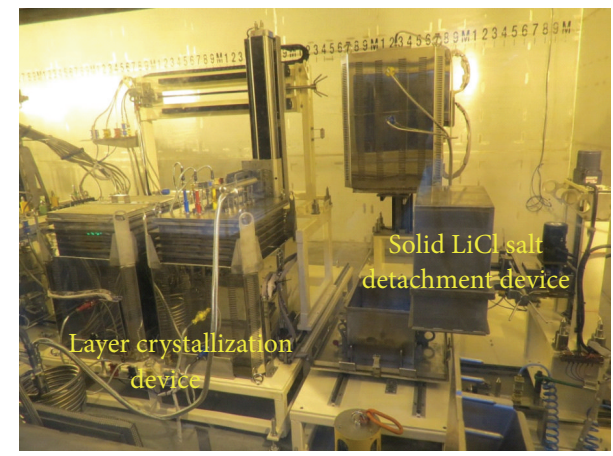

FIgURE 15: Photo of PRIDE engineering-scale $\mathrm{LiCl}$ waste salt treatment apparatus.

salt recovery). Finally, all the remaining rare earth oxides or oxychlorides were fabricated as a final waste form in the immobilization step.

The PRIDE engineering-scale rare earth separation apparatus (maximum batch size: $25 \mathrm{~kg}$-eutectic salt/batch) that consists of three devices, a rare earth precipitation, a solid eutectic salt detachment, and a layer separation, is shown in Figure 16. 

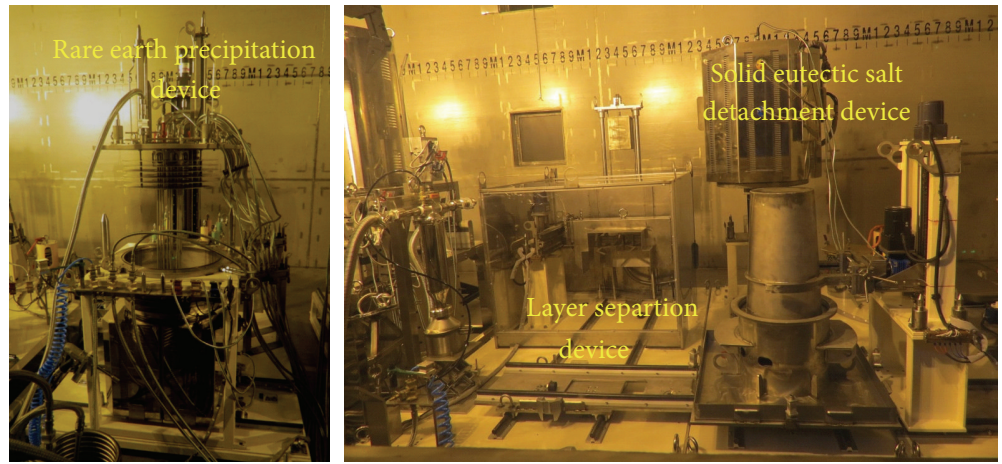

FIGURE 16: Photo of PRIDE engineering-scale rare earth separation apparatus.

(3) Residual Waste Solidification Process. In order to treat waste salt for final disposal, a dechlorination approach was adapted, where metal chloride waste was dechlorinated and thermally stabilized by using the synthetic inorganic composite SAP composed of $\mathrm{SiO}_{2}, \mathrm{Al}_{2} \mathrm{O}_{3}$, and $\mathrm{P}_{2} \mathrm{O}_{5}$, and its resultant product was sintered with a conventional borosilicate glass to obtain a monolithic wasteform.

The rare earth precipitates from the eutectic waste salt treatment process must be immobilized to a chemically stable solid wasteform for long-term storage in a geological environment. To immobilize rare earth oxide/oxychlorides, the solidifying matrix, ZIT, composed of $\mathrm{Zn}_{2} \mathrm{TiO}_{4}-\mathrm{CaHPO}_{4}{ }^{-}$ $\mathrm{SiO}_{2}-\mathrm{B}_{2} \mathrm{O}_{3}$ has been developed.

To realize the immobilization method, the lab-scale solidification process which consists of crushing, pulverizing, mixing/reacting and sintering equipment was used. Up to now, the unit equipments have been developed to obtain a proper performance and their processing conditions have been investigated to abstract the scale-up factors.

Table 2 shows the chemical durability of wasteforms and some physical properties for two wasteforms, SAP and ZIT wasteform. Leach-resistance of radionuclides was comparable to other radioactive wasteforms and the wasteforms had similar physiochemical properties, compared with silicate and phosphate glassy waste form [20].

\section{Pyroprocess-Integrated Inactive Demonstration Facility}

PRIDE has been constructed and operated as an engineering scale demonstration facility for pyroprocess studies [21]. The objective of PRIDE is to support integrated pyroprocessing demonstration and equipment development which are essential to realize the pyroprocessing. PRIDE is an integrated pyroprocessing system with unit reactor of $50 \mathrm{kgHM} / \mathrm{batch}$ capacity. It will use depleted uranium with surrogate materials to show integrated performance and scale-up issues of full-spectrum pyroprocessing technology.

PRIDE is a three-story building and it has a large-scale argon atmosphere cell ( $40.3 \mathrm{~m}$ length, $4.8 \mathrm{~m}$ width, $6.4 \mathrm{~m}$ height) at the second floor. The argon cell is equipped with cell operation equipments (small and large transfer systems, windows, cell lights, feed-through, etc.) and utilities. All process equipments are remotely operated and maintained by using remote handling systems such as 34 pairs of mechanical "Master Slave Manipulators" (MSMs), a "Bridge transported Dual arm Servo Manipulator" (BDSM), and an overhead crane [22]. Not only the remote handling systems but also all process equipments and devices for the use in the PRIDE were designed as an assembly of modules considering easy maintenance. The special interface between modules and equipments was devised to assemble and disassemble the modules.

The argon utility system of PRIDE was also developed for maintaining the cell atmosphere within the desired operating parameters (concentration of oxygen and moisture $<50$ parts per million (ppm), respectively, the pressure $(-10 \mathrm{mmAq}$ $-100 \mathrm{mmAq})$ and the temperature $\left.\left(28 \sim 40^{\circ} \mathrm{C}\right)\right)$. The argon utility system consists of argon cell recirculation and cooling system, the purification system, and the relief system. The recirculation and cooling system controls the pressure and temperature of the cell within the above operation conditions, and the purification system removes oxygen and moisture from the cell.

Recently, major process equipments such as electrolytic reducer, cathode processor, electrorefiner, salt transfer system, salt distiller, LCC type electrowinner, residual actinide recovery apparatus, cadmium distiller, and waste molten salt treatment apparatus were installed in the PRIDE argon cell (Figure 17), and voloxidizer, salt waste form fabrication system, $\mathrm{UCl}_{3}$ fabrication system, and uranium ingot melting furnace were installed at the first floor of PRIDE. The initial operation test of the argon system and evaluation of remote operability of cell equipment are being performed.

\section{Conclusion}

KAERI has developed an environment-friendly and proliferation resistant pyroprocessing for spent fuel treatment to recover useful materials such as uranium, plutonium, and reduce the volume and radiotoxicity of spent fuel. Through the last decade, $\mathrm{R} \& \mathrm{D}$, some innovative technologies such as an advanced voloxidation, a high-capacity electrolytic reduction, a high-throughput electrorefining with a graphite cathode, a mesh-type liquid cadmium cathode electrowinning, and waste salt regeneration by crystallization method, have 
TABLE 2: Some properties of two wasteforms.

\begin{tabular}{lcc}
\hline Property & SAP wasteform & ZIT wasteform \\
\hline Radionuclide leach rate, $\mathrm{g} / \mathrm{m}^{2}$ day & $10^{-4} \sim 10^{-3}$ for Cs/Sr & $<10^{-5}$ for rare earth \\
Wasteform leach rate, $\mathrm{g} / \mathrm{m}^{2}$ day & $10^{-2}$ & $10^{-3}$ \\
Density, g/cm & $3.7 \sim 4.2$ \\
Thermal conductivity, W/mK & $2.35 \sim 2.40$ & 1.7 \\
Thermal capacity, J/gK & $1.1 \sim 1.4$ & 0.65 \\
Glass transition temperature, $\mathrm{K}$ & $0.96 \sim 1.07$ & - \\
Thermal expansion coefficient, $\mathrm{K}^{-1}$ & $753 \sim 800$ & $3.0 \times 10^{-6}$ \\
Microhardness, GPa & $4.76 \pm 0.15$ & 5.5 \\
\hline
\end{tabular}

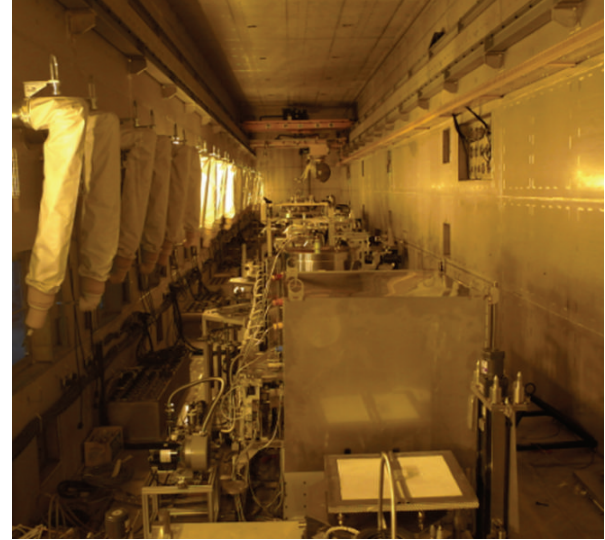

FIgURE 17: Inside view of the PRIDE argon cell.

been tested successfully. PRIDE facility has been constructed at KAERI and advanced technologies in engineering-scale are planned to be demonstrated in PRIDE. The PRIDE will verify the performance of equipments, interaction between units, remote operability, facility management system, and process monitoring. For the commercialization of pyroprocessing, knowledge of a scale-up is essential and PRIDE engineering-scale demonstrations compared to laboratoryscale tests which has been studied to date will give the scaleup information especially on the batch size effects and process yields affected by the equipment size. Therefore, the PRIDE engineering-scale tests will evaluate the technical feasibility, economic feasibility, and nonproliferation acceptability of pyroprocessing.

\section{References}

[1] I. S. Kim, C. S. Seo, H. S. Shin, Y. S. Hwang, and S. W. Park, "Characteristics of reduced metal from spent oxide fuel by lithium," Journal of the Korean Nuclear Society, vol. 35, no. 4, pp. 309-317, 2003.

[2] J. M. Shin and J. J. Park, "Trapping characteristics of cesium in off-gas stream using fly ash filter," The Korean Journal of Chemical Engineering, vol. 18, no. 6, pp. 1010-1014, 2001.

[3] Y. H. Kang, J. H. Lee, S. C. Hwang, J. B. Shim, E. H. Kim, and S. W. Park, "Electrodeposition characteristics of uranium by using a graphite cathode," Carbon, vol. 44, no. 14, pp. 3142-3145, 2006.
[4] J. H. Jang, H. S. Kang, Y. S. Lee, H. S. Lee, and J. G. Kim, "Development of continuous Ingot casting process for uranium dendrites in pyroprocess," Journal of Radioanalytical and Nuclear Chemistry, vol. 295, no. 3, pp. 1743-1751, 2013.

[5] H. S. Kang, J. H. Jang, Y. S. Lee, H. S. Lee, and J. G. Kim, "Development of engineering-scale ingot casting equipment for dendritic uranium deposit," in Proceedings of the International Conference on Nuclear Chemistry for Sustainable Fuel Cycles (ATALANTE '12), Le Corum Montpellier, France, September 2012.

[6] T. Hijikata and T. Koyama, "Development of high temperature transport technologies for liquid cadmium in pyrometallurgical reprocess," Journal of Power and Energy Systems, vol. 3, no. 1, pp. 170-178, 2009.

[7] S. Paek, S. H. Kim, D. S. Yoon, H. Lee, and D. H. Ahn, "Performance of the mesh-type liquid cadmium cathode structure for the electrodeposition of uranium from the molten salt," Radiochimica Acta, vol. 98, no. 12, pp. 779-783, 2010.

[8] J. B. Shim, Y. J. You, S. W. Kwon et al., “Thermodynamic and experimental approaches for an effective recovery of actinides from a spent $\mathrm{LiCl}-\mathrm{KCl}$ salt," in Proceedings of the International Pyroprocessing Research Conference, Jeju Island, Republic of Korea, August 2008.

[9] T. J. Kim, Y. Jung, S. H. Kim, S. W. Paek, and D. H. Ahn, "Elucidation of electrode reaction of $\mathrm{EuCl}_{3}$ in $\mathrm{LiCl}-\mathrm{KCl}$ eutectic melts through CV curve analysis," Bulletin of the Korean Chemical Society, vol. 32, no. 3, pp. 863-866, 2011.

[10] K. R. Kim, T. J. Kim, S. Paek, D. H. Ahn, J. Y. Park, and I. S. Hwang, "Computational electrochemo-fluid dynamics modeling in a uranium electrowinning cell," in Proceedings of the 3rd International Nuclear Chemistry Congress (INCC '11), Palermo Sicily, Italy, September 2011.

[11] Argonne National Laboratory, "Chemical technology division annual technical report 1987,” Tech. Rep. ANL-88/19, 1988.

[12] D. H. Ahn, J. B. Shim, S. W. Paek et al., "Development of volume reduction technology for PWR spent fuel by pyroprocessing: development of the electrowinning system for TRU recovery," Tech. Rep. KAERI/RR-3400, Atomic Energy Research Institute, Korea, 2011.

[13] J. B. Shim, K. S. Han, S. H. Kim et al., "Effects of $\mathrm{CdCl}_{2}$ on the residual actinides recovery (RAR) system of a spent $\mathrm{LiCl}-\mathrm{KCl}$ salt," in Proceedings of Global, Paris, France, September 2009.

[14] K. Kinoshita, T. Inoue, S. P. Fusselman et al., "Separation of uranium and transuranic elements from rare earth elements by means of multistage extraction in $\mathrm{LiCl}-\mathrm{KCl} / \mathrm{Bi}$ system," Journal of Nuclear Science and Technology, vol. 36, no. 2, pp. 189-197, 1999. 
[15] M. F. Simpson and M. L. D. Gougar, "Two-site equilibrium model for ion exchange between monovalent cations and zeolite-A in a molten salt," Industrial and Engineering Chemistry Research, vol. 42, no. 18, pp. 4208-4212, 2003.

[16] R. K. Ahluwalia, H. K. Geyer, C. Pereira, and J. P. Ackerman, "Modeling of a zeolite from molten salt," Industrial and Engineering Chemistry Research, vol. 37, pp. 145-153, 1998.

[17] S. Phongikaroon and M. F. Simpson, "Equilibrium model for ion exchange between multivalent cations and zeolite- $\mathrm{A}$ in a molten salt," AIChE Journal, vol. 52, no. 5, pp. 1736-1743, 2006.

[18] D. Lexa, "Occlusion and ion exchange in the molten (lithium chloride + potassium chloride + alkaline-earth chloride) salt + zeolite $4 \mathrm{~A}$ system with alkaline-earth chlorides of calcium and strontium and in the molten (lithium chloride + potassium chloride + actinide chloride) salt + zeolite $4 \mathrm{~A}$ system with the actinide chloride of uranium," Metallurgical and Materials Transactions B, vol. 34, no. 2, pp. 201-208, 2003.

[19] H. S. Park, I. T. Kim, Y. J. Cho, M. S. Son, and H. C. Eun, "Removal behavior of Cs from molten salt by using zeolitic materials," Journal of Radioanalytical and Nuclear Chemistry, vol. 283, no. 2, pp. 267-272, 2010.

[20] W. E. Lee, M. I. Ojovan, M. C. Stennett, and N. C. Hyatt, "Immobilisation of radioactive waste in glasses, glass composite materials and ceramics," Advances in Applied Ceramics, vol. 105, no. 1, pp. 3-12, 2006.

[21] G.-S. You, I.-J. Cho, W.-M. Choung et al., "Concept and safety studies of an integrated pyroprocess facility," Nuclear Engineering and Design, vol. 241, no. 1, pp. 415-424, 2011.

[22] J. K. Lee, H. J. Lee, B. S. Park, and K. Kim, "Bridge-transported bilateral master-slave servo manipulator system for remote manipulation in spent nuclear fuel processing plant," Journal of Field Robotics, vol. 29, no. 1, pp. 138-160, 2012. 


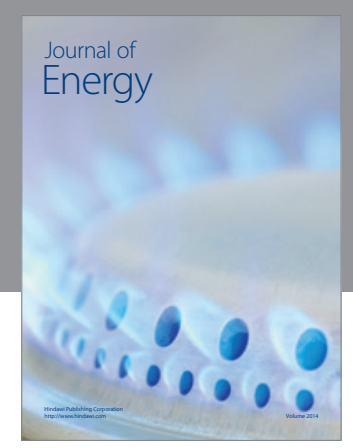

Journal of

Industrial Engineering
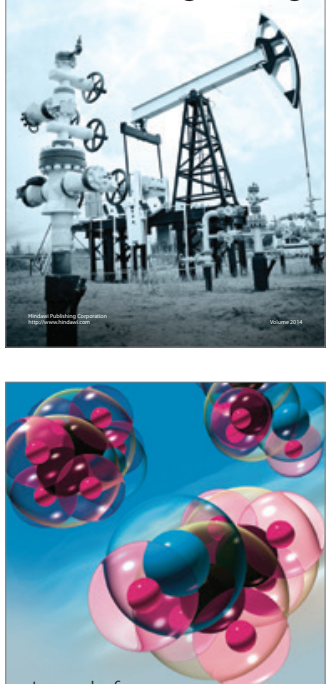

Fuels
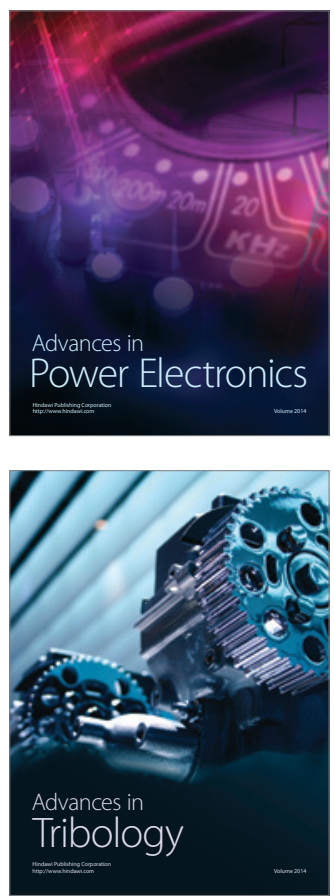

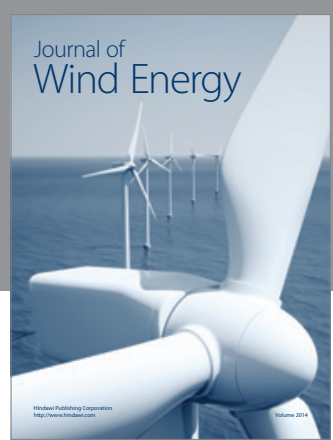

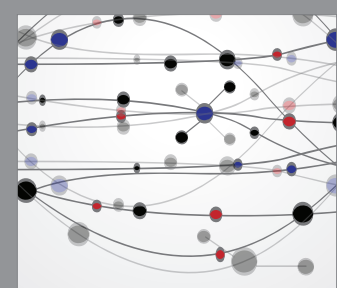

The Scientific World Journal

Submit your manuscripts at http://www.hindawi.com

Journal of

Structures
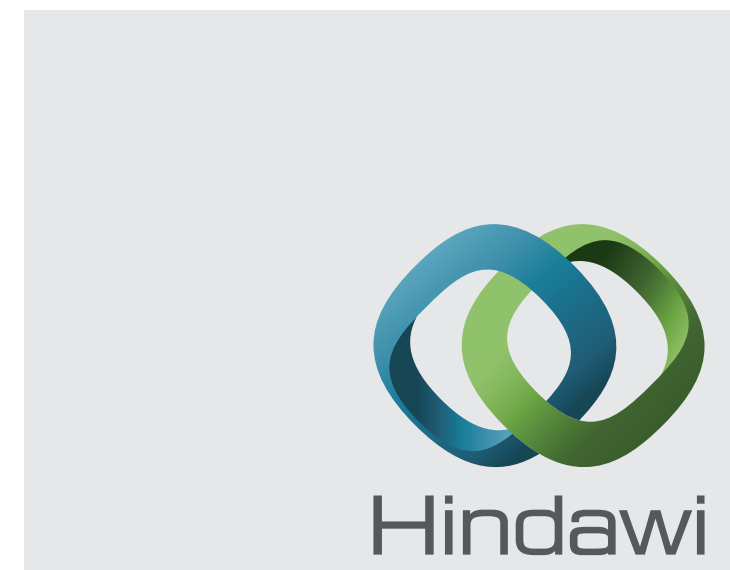

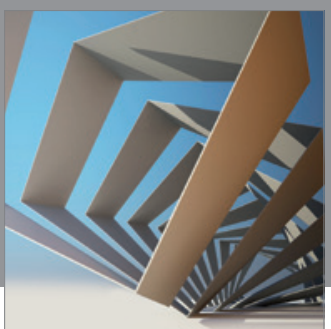

Rotating

Machinery
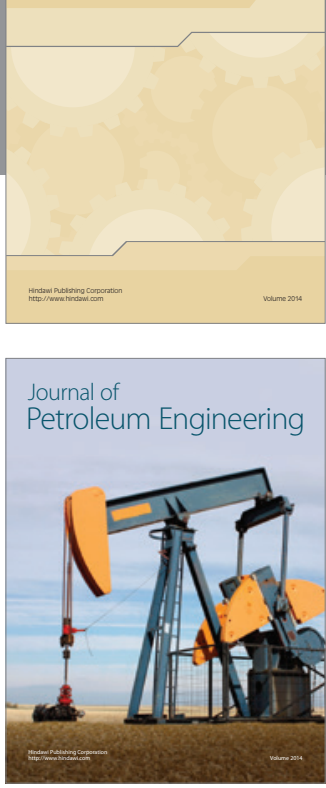

Journal of

Solar Energy
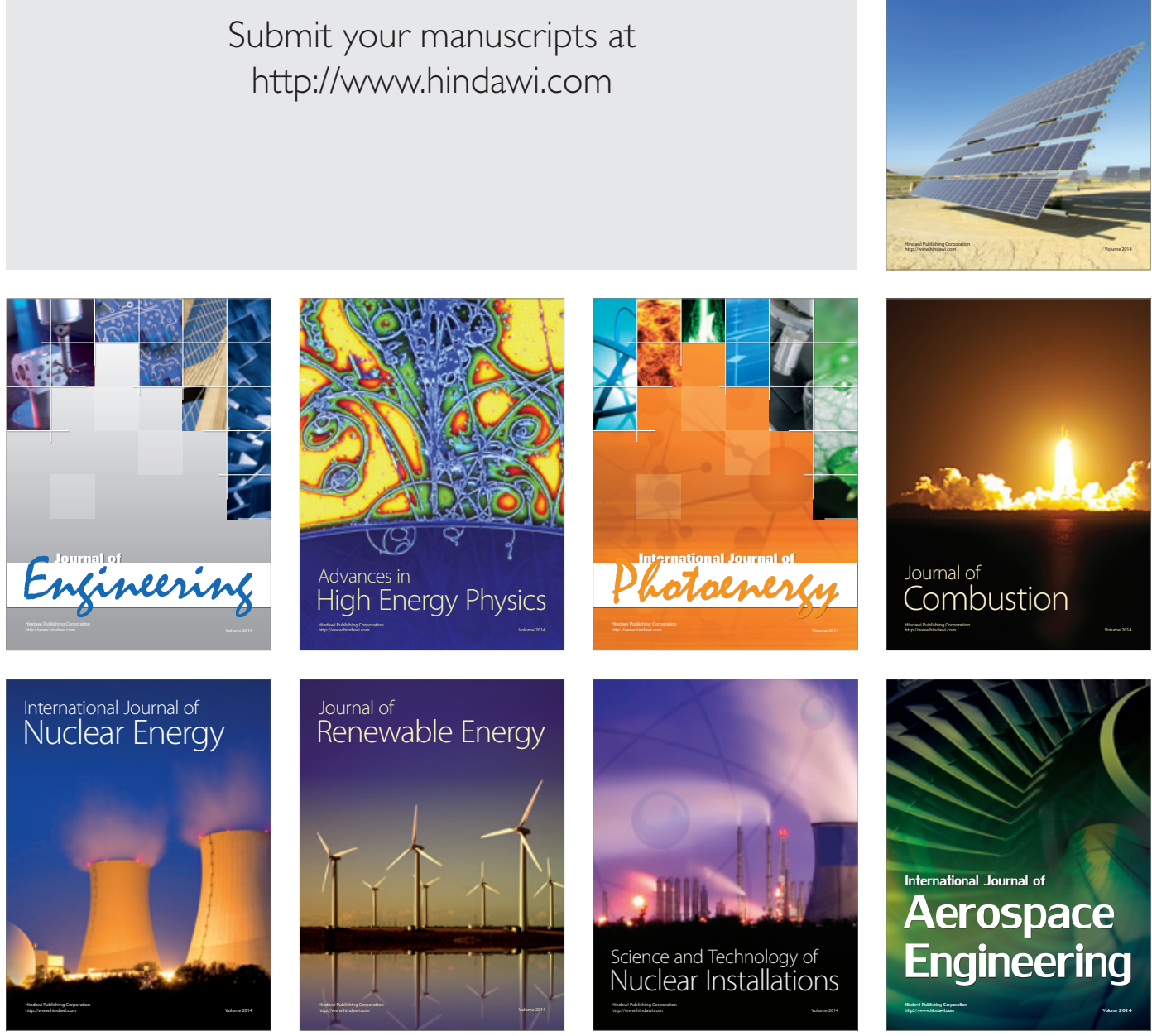